\title{
CHIA TOHUMUNUN KİMYASAL, ANTİOKSİDAN VE ANTİMİKROBİYAL ÖZELLİKLERİ
}

\author{
E. Bilge Sur ${ }^{1}$, Şeniz Karabıyıklı Çiçek ${ }^{2 *}$ \\ *1 Sivas Cumhuriyet Üniversitesi, Zara Ahmet Çuhadaroğlu MYO, Gıda İşleme Bölümü Sivas, Türkiye \\ ${ }^{2}$ Tokat Gaziosmanpaşa Üniversitesi, Mühendislik ve Mimarlık Fakültesi, Gıda Mühendisliği Bölümü, Tokat, \\ Türkiye
}

Geliş / Received: 19.03.2021; Kabul / Accepted: 07.06.2021; Online bask1 / Published online: 07.07.2021

Sur, E.B., Karabıyıkl1-Çiçek, Ş. (2021). Chia tohumunun kimyasal, antioksidan ve antimikrobiyal özellikleri. GIDA (2021) 46 (4) 971-979 doi: 10.15237/gida. GD21055.

Sur, E.B., Karabyylkh-Ciçek, S. (2021). Chemical, antioxidant and antimicrobial properties of chia seed. GIDA (2021) 46 (4) 971-979 doi: 10.15237/gida. GD21055.

ÖZ

Salvia hispanica L. olarak bilinen chia tohumu, Lamiaceae ailesine ait oval şeklinde, beyaz, gri ve çoğunlukla siyah renkte, küçük tohumlu tek ylllık otsu bir bitkidir. Zengin besin öğesi içeriği ve sağllk üzerine etkisi nedeniyle popüler bir fonksiyonel gıda olarak kullanılmaktadır. Yapılan çalışmalarda chia tohum yağının sahip olduğu esansiyel yağların chia ve eklendiği ürüne antimikrobiyel etki kazandırdı̆̆1 görülmüştür. Bu antimikrobiyel etkinin genel olarak Gram pozitif ve Gram negatif bakteriler gibi mikroorganizmalar üzerinde inhibitif ve bakteriostatik etki gösterdiği tespit edilmiștir. Ayrıca çalışmalarda chiada bulunan flavonoidlerin ve tokoferolün tohumun antioksidan kapasitesinden sorumlu temel yapılar olduğu da tespit edilmiştir. Chia tohumlarının ve ekstraktının antioksidan kapasitesi üzerine yapılmış olan çalışmalarda lipit peroksidasyonunu engellediği, oksidatif strese karşı hücreyi koruduğu bulunmuştur. Bu derleme çalşmasında günümüzde kullanım alanı giderek genişleyen chia tohumunun antimikrobiyel ve antioksidan özelliklerinin derlenmesi ile fonksiyonel gida üretimine katkısının değerlendirilmesi amaçlanmıştır.

Anahtar kelimeler: Chia (Salvia hispanica) tohumu, antimikrobiyel etki, antioksidan etki, fonksiyonel gida

\section{CHEMICAL, ANTIOXIDANT AND ANTIMICROBIAL PROPERTIES OF CHIA SEED}

\begin{abstract}
Chia seed, known as Salvia hispanica L., is an oval-shaped, one-year herbaceous plant belonging to the Lamiaceae family with small seeds of white, gray or black (mostly) color. It is used as a popular functional food for its health effects associated with its rich nutrient content. Studies have shown that the essential oils of chia seed oil have an antimicrobial effect on chia and the product it is added to. It has been determined that this antimicrobial effect generally exerts an inhibitory and bacteriostatic effect on microorganisms such as Gram-positive and Gram-negative bacteria. In addition, studies have found that the flavonoids and tocopherol found in Chia are the basic structures responsible for the antioxidant capacity of the seed. Studies on the antioxidant capacity of chia seeds and extract have been found to inhibit lipid peroxidation and protect the cell against oxidative stress. In this review study, it was aimed to compile the antimicrobial and antioxidant properties of chia seeds, whose area of use is gradually expanding, and to evaluate its contribution to functional food production.
\end{abstract}

Keywords: Chia (Salvia hispanica) seed, antimicrobial effect, antioxidant effect, functional food

\footnotetext{
*Yazışmalardan sorumlu yazar / Corresponding author

(1): seniz.karabiyikli@gop.edu.tr, (1): (+90) 356252 1616-2884

且: (+90) 3562521729

E. Bilge Sur; ORCID no: 0000-0003-0500-8303

Şeniz Karabıyıkı Çiçek; ORCID no: 0000-0001-9287-9400
} 


\section{GİRİ̧̧}

Salvia hispanica olarak bilinen chia, kökeni kuzey Guatamala ve güney Meksika'ya dayanan tek y1llik bir bitkidir. Lamiaceae ailesine ait Chia bitkisi Salba olarak bilinmektedir. Bu cinsin en sik kullanilan türü Salvia hispanica'der (Marcinek ve Krejpcio, 2017).

Salvia türleri genellikle Akdeniz iklim kuşağında yetiştirilebilen adaptasyon sınırları geniş, çok yıllık, keskin kokulu ve birçoğu uzun gün bitkisi olma özelliğine sahipken, Salvia hispanica L. tek yıllık, nötr kokulu, adaptasyon sinırları dar ve çevresel koşullara toleransı sinırlı, kısa gün bitkisidir (Orozco vd., 2014). Tropik ya da 1 llman iklimlerde yetişen tek yıllık ve hermafrodit bir bitki olup, çok düşük sıcaklıklara duyarlı olduğu için de tohumun gelişim süreci için en ideal sicaklik 16-26 ${ }^{\circ} C^{\prime}$ dir (Bochicchio vd., 2015). Tohum olgunlaşması sonbahar sonu gerçekleştiğinden ve sıcaklık değişimlerinden çok fazla etkilendiğinden ülkemizde kültürünün yapılması zorlaşmaktadır. Chia tohumunun ticari olarak üretimi Bolivia ve Paraguay'da yapılsa da son y1llarda yaygin olarak Meksika, Avustralya ve Arjantin gibi ülkelerde de ekimi yapılmaktadır (Sosa vd., 2016). Üretim miktarı yetiştirildiği bölgeye göre farklılık göstermekle birlikte Dünyadaki yllık üretim miktarı 150000 ton civarında değişen chia, tohum olarak ekmekte, kahvaltılık gevreklerde, hazır yemeklerde, süt ürünlerinde ve chia tohumu olarak; yağ1 çıkartılarak katı ve sıvı yağ olarak tüketimde ve gıda takviyelerinde; kısmen yağdan arındırılmış yüksek proteinli chia olarak fermente süt ürünlerinde, meyve sularında, aromalı içeceklerde, gida takviyelerinde; diyet lifi olarak da meyve ve sebze sularinda, gida takviyelerinde kullanilmaktadır (Anonim, 2021).

Salvia türlerinin büyük bir kısmı dünyada yüksek antioksidan kapasitesi nedeniyle bitkisel tedaviler için kullanılırken, bazı bölgelerde kuru yaprakları çay ve baharat olarak kullanılmaktadır (Arslan ve ark. 2015). Chia tohumları gıda sanayinde; çeşitli tahıl unlarına karıştırılarak ekmek yapımında, yoğunlaştırıcı olarak yemeklerde, salatalarda, sütlü tatlılarda ve şekerlemelerde kullanılmaktadır ( $\mathrm{Lu}$ ve Foo, 2002). Ülkemizde ise kullanımı çoğunlukla tohum şeklinde olup, ihracatı yıllara göre değişiklik göstermekle birlikte yılllk ortalama 1200 ton civarında ihracatı yapilmaktadır (Özgüven vd., 2005).

“Süper besin" olarak adlandırılan ve günümüzde popülaritesi gittikçe artmakta olan Chia bitkisinin (Salvia hispanica) iklim değişikleri, toprak koşulları, ekim alanı, hasat yllı gibi faktörler bileşenlerinde değişikliğe neden olmakla birlikte protein, yağ, karbonhidrat, diyet posas1, niasin, A vitamini, potasyum, kalsiyum, magnezyum ve fosfor içeriği açısından yüksek; sodyum, demir çinko ve C vitamini içeriği açısından ise düşüktür. Chia tohumunun antimikrobiyel ve antioksidan kapasitesinden sorumlu ve temel bileşenlerinden olan esansiyel yağ asitlerinin \%55-60'nn $\alpha$ linolenik yă̆ asidi (omega-3) ve \%18-20'sini linoleik yağ asidi (omega-6) oluşturmaktadır (Yurt ve Gezer, 2018).

\section{Chia tohumunun kimyasal kompozisyonu ve besin bileşenleri}

Chia tohumu birçok tohum çeşidine göre daha fazla miktarda yağ, protein, diyet posası ve $\alpha$ linolenik (omega-3) yağ asidi içermektedir (Scapin vd., 2016). Chia tohumunun bileşenlerinde farklılığa sebep olabilecek birçok etken olmakla birlikte genel olarak komposizyonu Çizelge1'deki gibidir.

Chia tohumunun protein içeriği \%15-23 aralı̆̆ında olup, esansiyel tüm amino asitleri yeterli miktarlarda içermektedir (Brandão vd. 2019). Ayrıca globülin (\%52), albümin (\%17.3), gliadin $(\% 14.5)$ ve prolamin $(\% 12.7)$ proteinlerini, bunun yanı sıra prolin, lösin, izolösin ve fenilalanin gibi hidrofobik özellikteki amino asitleri de bünyesinde bulundurmaktadır (Kulczyński vd., 2019).

Chia tohumunda bulunan yağ oran1 \%25-40 arasında değişmektedir. Bunun \%68'i omega-3 çoklu doymamış yağ asidi, \%19'u omega-6 çoklu doymamış yă̆ asidi, \%6's1 tekli doymamış yă̆ asidi ve \%16.4'ü doymuş yağ asidi formundadır (Timilsena vd., 2017; Villanueva-Bermejo vd., 2019). Chia tohumundaki önemli yağ asitlerinden omega- 3 çoklu doymamış yağ asidi $\alpha$-linolenik asit 
(ALA), omega-6 çoklu doymamış yağ asidi linoleik asit (LA) formundadir (Bodoira vd., 2017). Bununla beraber $\% 5-10$ oranında oleik asit, \%6-7 oranında palmitik asit ve \%1-3 oraninda stearik asit içermektedir (Segura-Campos vd., 2014; da Silva Marineli vd., 2014; Ding vd., 2018). Yapılan çalışmalar çoklu doymamış yağ asitlerinin sıcaklığın artmasıyla azaldığını, protein içeriğinin ise yükseltinin artmasıyla azaldığını göstermiştir. Ayrıca düşük rakımda yetiştirilen chia tohumu yağlarının yüksek rakımdakilere göre daha fazla doymuş yağ asidi içeriğine sahip olduğu (Ayerza, 2010 ), erken hasatın chia tohumunda $\alpha$-linolenik asit içeriğinde $\% 23$ oranında azalışa neden olduğu, linoleik asit ve lignin seviyelerinde ise artış sağladığı belirtilmiştir (Peiretti ve Gai, 2009).

Çizelge 1. Chia tohumunun kimyasal bileşimi (USDA, 2020)

\begin{tabular}{|l|c|}
\hline Bileşen & $\begin{array}{c}\text { Miktar } \\
(100 \mathrm{~g})\end{array}$ \\
\hline Enerji (kkal) & 569 \\
\hline Karbonhidrat $(\mathrm{g})$ & 40.62 \\
\hline Protein $(\mathrm{g})$ & 15.62 \\
\hline Yağ $(\mathrm{g})$ & 31.25 \\
\hline Diyet lif $(\mathrm{g})$ & 34.4 \\
\hline $\mathrm{Ca}(\mathrm{mg})$ & 625 \\
\hline $\mathrm{Fe}(\mathrm{mg})$ & 7.5 \\
\hline $\mathrm{Mg}(\mathrm{mg})$ & 335 \\
\hline $\mathrm{P}(\mathrm{mg})$ & 860 \\
\hline $\mathrm{K}(\mathrm{mg})$ & 406 \\
\hline $\mathrm{Na}(\mathrm{mg})$ & 16 \\
\hline Zn $(\mathrm{mg})$ & 4.5 \\
\hline $\mathrm{C}$ vitamini $(\mathrm{mg})$ & 15 \\
\hline $\mathrm{B}_{1}$ vitamini $(\mathrm{mg})$ & 0.62 \\
\hline $\mathrm{B}_{2}$ vitamini $(\mathrm{mg})$ & 0.2 \\
\hline $\mathrm{B}_{3}$ vitamini $(\mathrm{mg})$ & 8.8 \\
\hline A vitamini $(\mathrm{IU})$ & 54 \\
\hline E vitamini $(\alpha-$ tokoferol$)$ & 0.5 \\
\hline
\end{tabular}

Chia tohumu \%35 oranında karbonhidrattan oluşmaktadır ve bu içeriğin \%34'ü diyet lifidir (Lee, 2009). Diyet lifi tetrasakkarit yapıda 4-metil$\alpha$-D-glukoronopiranozil ve dallı yapiya sahip $\beta$-Dksilopronozil polisakkaritlerinden oluşmaktadır. Monosakkarit yapısı ise D-ksiloz ve D-mannoz (\%16), D-arabinoz (\%2), D-glikoz (\%6), Dgalaktoüronik asit (\%3) ve glukronik asit (\%12) içermektedir (Capitani vd., 2012). Diyet lifi içeriğinin, çözünmeyen fraksiyonu yaklaşık \%8593'ü temsil ederken, çözünür fraksiyonu \%7 ile \%15 arasındadır (da Luz vd., 2012). Çözünür liflerin postprandial glisemiyi düşürdüğü, ayrıca hem çözünür hem de çözünmez lifin, iştahı ve/veya sonraki gıda alımını azalttığ1 görülmüştür (Tamargo vd., 2018).

Chia tohumu, kendi ağırlı̆̆ının 27 katı kadar su tutma özelliğine sahiptir. Tohumun su teması ile kabuktaki polisakkarit yapı suyu tutarak yapısında ksiloz, glikoz ve 4-metil glukuronik asit gibi bileşenler bulunduran ve tohum etrafinda jelatin kapsül gibi bir yap1 oluşturmaktadır (OronaTamayo vd., 2017). Oluşan bu jel yapı guar gum, aljinat ve jelatinle kıyaslandığında, bu jel yapının daha iyi su ve yağ tutma kapasitesine sahip olduğu, bunun yanında emülsiyon stabilizasyonu sağlama özelliğine de sahip olduğu belirtilmektedir (Campo vd., 2017). Chia tohumu sahip olduğu bu özelliklerinden dolayı gidalarda emülsifiyer, su tutucu ve stabilizatör olarak kullanılmaktadır (Goh, 2016).

Chia tohumu içeriğinde gallik asit, kafeik asit, klorojenik asit, rozmarinik asit, myristin, kersetin ve kamferol gibi fenolik bileşikleri ayrıca tokoferol, karotenoid, vitaminler ve baz1 peptitler gibi antioksidan bileşikleri bulundurmaktadır (Alcântara vd., 2019). Bununla birlikte iyi bir B vitamini kaynağı olup, yüksek niasin içeriğine sahiptir (Beltrán-Orozco vd., 2003).

Chia tohumunun fonksiyonel besin bileşenlerini yüksek oranda içermesi chia tohumunun kardiyovasküler hastalıklar, diyabet, kanser ve obezite gibi kronik hastalıklardan korunmaya önemli ölçüde yardımcı olduğunu göstermektedir (Meyer ve Groot, 2017; Zettel ve Hitmann, 2018).

Yapılan son çalışmalar, chia tohumunun diyet posas1, mineral, protein ve yağ (özellikle alfalinolenik asit) gibi sağllklı bileşenleri içermesinden dolay1, tüketiminin postprandiyal kan şekerini düşürdügünü ve sistolik kan basıncını azalttığını, doygunluk indeksini arttırdığını göstermiştir (Jin vd., 2012). Bu nedenle de kilo kaybı için kullanılabilecek bir ek gıda olmaktadır (Vuksan vd., 2017a). 
Omega-3 yağ asitlerince zengin bir kaynak olan chia tohumunun günlük beslenmeye eklenmesi ile kan kolesterol düzeyinin düzenlenmesi sağlanmaktadır (Alonso-Calderón vd., 2013). Ayrıca yapılan çalışmalarda chia yağının tümör büyümesini ve metastazı azalttığı da görülmüştür.

Chia tohumundaki diyet lifinin büyük bir kısmını oluşturan çözünür posa $(53.45 \mathrm{~g} / 100 \mathrm{~g})$, suyu yapisinda tutarak doygunluk hissini artirip sindirimi yavaşlatmakta, yemek sonrası kan glikozunun yavaş yükselmesini sağlayarak insülin salınımını düşürmektedir (Vuksan vd., 2017b). Chia tohumu buğdayda bulunan bir protein olan gluten içermemektedir. Bundan dolayı da çölyak hastaları tarafindan güvenle tüketilebilmektedir (Doğan, 2019).

\section{Chia Tohumunun Antioksidan Özellikleri}

Serbest radikaller küçük moleküller olup, atomik veya moleküler orbitallerinde bir veya daha fazla ortaklanmamıs elektron bulunduran kimyasal türlerdir (Wang vd., 2021). Çoğunlukla polifenolik yapıda olup tüm meyvelerde, sebzelerde, mikroorganizmalarda, mantarlarda ve hayvansal dokularda bulunmaktadırlar (Baykal vd., 2002). Antioksidanlar organizmay1 nörolojik hastaliklardan, iltihaplanmalardan, immün yetmezlikten, kalp hastalıklarından ve kanserden korumaktadır (Grancieri vd., 2019).

Chia tohumu ve yağları, tokoferoller, fitosteroller, karotenoidler ve polifenolik bileşikler gibi çok sayıda doğal antioksidan içermektedir (Erdoğdu ve Geçgel, 2019). Polifenolik bileşikler, chia tohumlarının antioksidan aktivitesine katkıda bulunan en önemli komplekslerdir. Serbest radikalleri temizleme, iyonları şelatlama ve hidrojen bağışlama yeteneklerine sahip oldukları iyi bilinmektedir (de Falco vd., 2017).

İkincil metabolitler arasında yer alan fenolik maddeler, doğal antioksidanların en önemli gruplarını oluşturlar (Akıcı, 2018). Gallik asit, kafeik asit, klorojenik asit, rosmarinik asit, myristin, kuarsetin ve kampferol gibi fenolik bileşikleri içeren chia tohumunun bileşimindeki en önemli antioksidan bileşik tokoferollerdir (238427 mg/kg) (Rahman vd., 2017). Bileşimindeki antioksidan bileşikler kanser ve kalp krizi riskini azaltmakta, alzheimer ve parkinson hastalığ1 gibi bazı rahatsızlıklara karşı koruma sağlamaktadır (Hrncic vd., 2020).

Chia tohumunun antioksidan kapasitesinden sorumlu temel yapilarin flavonoidler ve tokoferol olduğu Pellegrini vd. (2003)'nin yapmış oldukları çalışmada bildirilmiştir ve yüksek antioksidan kapasitesi tohumun uzun süre saklanabilmesini sağlamaktadır.

Reyes-Caudillo vd. (2008)'nin chia tohum fenoliklerinin antioksidan aktivitelerini belirledikleri çalışmada, fenolik bileşikler etanol içinde hidroklorik asit ile ekstraksiyon ve etanolle ekstraksiyon olmak üzere iki ekstraksiyon yöntemi kullanmışlar ve ABTS radikal temizleme, $\beta$ Karoten linoleik asit model sistemi ( $\beta$-CLAMS) ve fosfolipid lipozomlarin peroksidasyonu yöntemleri ile ekstraktların \%0.020, \%0.050, $\% 0.075$ ve $\% 0.01$ konsantrasyonlardaki antioksidan aktiviteleri belirlenmiştir. Kullanılan yöntemlerde antioksidan aktivitelerin konsantrasyonun artmasıyla arttı̆̆1 (0.29-1.09) tespit edilmiştir.

Burger üretiminde hayvansal yağ yerine chia yağ kullanımının denendiği bir çalışmada, chia ve keten tohumu karışımından iyonik jelasyon tekniği ile hazırlanan mikropartikül eklenen burgerlerin hem çiğ hem de pişmiş örneklerinde kontrol grubuna kiyasla, sağlık açısından daha uygun PUFA/SFA (0.62) ve n-6/n-3 (1.16) oranlarına sahip olduğunu ve daha yüksek lipit oksidasyonu direnci gösterdiği rapor edilmiştir (Heck vd., 2017).

Farklı oranlarda ( $\% 5 ; \% 10 ; \% 15$ ve $\% 20)$ chia yağ 1 ilave edilen dondurmalarda 60 günlük depolama boyunca omega-3 yağ asitlerinin ve oksidatif stabilitesinin değişimleri incelenmiş, chia yağı ilave edilmiş dondurmalarda omega-3 yağ asidi içeriğinin arttığ1, DPPH yöntemi ile dondurmaların peroksit değerlerinin ve chia yağ konstanrasyonun artmasiyla azaldığ1 ve izin verilen sinırların altında $\left(10\right.$ meq $\left.\mathrm{O}_{2} / \mathrm{kg}\right)$ olduğu tespit edilmiştir. (Ullah vd., 2017). 


\section{Chia Tohumunun Antimikrobiyel Özellikleri}

Chia tohumunun bileşenlerinde farklllık söz konusu olmakla birlikte genellikle \%25-40 oranında yağ elde edilmektedir. Chia tohumun yağ içeriğinin \%55-60'1nı $\alpha$-linolenik (omega-3) ve $\% 18-20$ 'sini linoleik (omega-6) esansiyel yağ asitleri oluşturmaktadır.

Esansiyel yağların antimikrobiyel aktiviteleri çalışmaların en çok araştırılan özelliği olmuştur. $\mathrm{Bu}$ yağların, etki dereceleri içerdikleri etken maddelerin çeşit ve miktarına bağlı olarak farklılık göstermektedir. Sinerjik, antagonistik ve aditif etkileşimlere sahip olan esansiyel yağların beraber kullanıldıklarında tek başına kullanıldıklarından daha iyi bir etki gösterdikleri yapılan çalışmalarda bildirilmiştir (Bayaz, 2014).

Esansiyel yağlar Gram negatif ve Gram pozitif bakteriler dahil, birçok mikroorganizma üzerinde antimikrobiyel etki göstermektedir. Bu yağlar, bakteri membranını parçalayarak membranla ilgili materyallerin hücre dışına çıkmasını sağlarken, bazılarının sahip olduğu lipofilik özellikleri sayesinde bakteri duvarını delerek hücrenin daha iç kısımlarına ulaştıkları bildirilmiştir (Ertürk vd., 2020; Güzel ve Ülger, 2020).

Esansiyel yağların doğal maddeler olarak gıdalardaki mikroorganizmaların gelişimini sınırlayan etkinliklerinin belirlenmesi üzerine yapılan çalışma sayısı gün geçtikçe artmaktadır. Luo ve vd. (2019)'nin yapmış olduğu çalışmada farklı konsantrasyonlarda hazırlanan chia müsilaj ve jelinin, 24 günlük süre sonunda Escherichia coli ve Staphylococcus aureus üzerinde yaklaş1k $\% 50$ ve $\% 40$ oranında inhibisyona sebep olduğu gözlenmiş; bu etkinin chianın sahip olduğu esansiyel yağlardan kaynaklandığı rapor edilmiştir. Bu çalışma ile, uzun süreli antimikrobiyel özelliğe sahip uçucu yağ yüklü yenilebilir filmlerin gerçekleştirilmesine de kaynak olacağy öngörülmüştür.

Bütün ve öğütülmüş chia tohumlarının Salmonella ve Clostridium cinslerinin yan1 sura Listeria monocytogenes, Pseudomonas aeruginosa, Escherichia coli ve Protens mirabilis gibi patojenlere karşı da antimikrobiyel etki gösterdiği; öğütülmüşs tohumların en güçlü antimikrobiyel etkisinin probiyotik mikroorganizmalardan Lactobacillus lactis $(11 \mathrm{~mm})$, Lactobacillus acidophilus $(8 \mathrm{~mm})$, Lactobacillus bulgaricus $(5 \mathrm{~mm})$, Lactobacillus paracasei (5 mm), Lactobacillus rhamnosus $(5 \mathrm{~mm})$ ve Streptococcus thermophilus'a (5 mm) karşı olduğu tespit edilmiştir (Kobus-Cisowska vd., 2019).

Chia tohumu esansiyel yağlarının gida kaynaklı patojen küflere karşı doğal fungistatik ve/veya fungisidal etkili bileşiklere sahip olduğu Elshafie vd. (2018)'nin yaptı̆̆1 çalışmada görülmektedir. $\mathrm{Bu}$ çalışmada değişik konsantrasyonlarda chia tohumu esansiyel yağlarının Aspergillus fumigatus, Penicillium expansum, Monilinia laxa üzerinde yüksek inhibisyon, Penicillium digitatum' $\mathrm{da}$ orta derecede inhibisyon, Aspergillus niger, Aspergillus flavus ve Fusarium oxysporum'da ise hafif bir inhibisyon yarattığ gözlenmiştir.

Divyapriya vd. (2016)'nin periodental hastalıklara neden olan Porphyromonas gingivalis, Fusobacterium nucleatum ve Aggregatibacter actinomycetemcomitans bakterilerine karşı farklı konsantrasyondaki chia ekstraktının etkisini inceledikleri çalışmada, disk difüzyon testi sonucu üç bakteri türünde sırasıyla $15 \mathrm{~mm}, \quad 16 \mathrm{~mm}, \quad 17 \mathrm{~mm}$ 'lik zon oluşumu gözlenmiştir ve bu antibakteriyel etkinin kompozisyonundaki esansiyel yağlardan kaynaklandığı ileri sürülmüştür.

Chia polifenolleri ayrica ortamdaki konsantrasyonlarına bağlı olarak farklı antimikrobiyel aktivite sergilemektedir. Düşük konsantrasyonlarda polifenoller, hücre zarındaki lipitler ve proteinlerle reaksiyona girmektedir ve böylece hücre zar1 yar1 geçirgen özelliğini kaybettiği için iyonlar ve diğer bileşenler hücreden sızmaktadır. Bu bileşiklerle kısa süreli temasın bir sonucu olarak, mikroorganizmalar bunlara dirençli hale gelmektedir. Ancak polifenollere veya bunların solüsyonlarına daha yüksek konsantrasyonlarda uzun süre maruz kalma, enzimler dahil olmak üzere proteinleri denatüre edip ve bakteriyel hücrelerdeki metabolizmayı bozarak bakteri ölümlerine neden olmaktadır. (Kobus-Cisowska vd., 2019). Ayrica chianin antibakteriyel ve antifungal özelliklerinin yanında 
antiviral aktiviteleri de ilgi çekmiş ve çalışmalarda rapor edilmiştir.

\section{SONUÇ}

Chia tohumunun iyi bir protein, diyet lifi, fenolik ve doymamış yağ asidi kaynağı olduğu, ülkemizde ve dünyada gün geçtikçe popülaritesinin artmakta olduğu, sağllk üzerine birçok olumlu etkisinin olduğu ve bundan dolay1 "süper besin" olarak isimlendirildiği yapılan çalışmalarda ortaya konmuştur. Fonksiyonel gıda bileşenlerini yüksek oranda sağlaması, chia tohumunun kardiyovasküler hastalıklar, diyabet, kanser ve obezite gibi kronik hastaliklardan korunmada önemli ölçüde etkisi olduğunu göstermektedir.

Chia tohumu sahip olduğu zengin besin içeriği sayesinde gida sanayi tarafindan emülsifiyer ve su tutucu ajan olarak son ürün özelliklerinin iyileştirilmesinde ve glütensiz ürün geliştirilmesinde kullanımı son yıllarda yaygınlaşmıştır. Bununla birlikte chia tohumu ve yağlarının, tokoferoller, fitosteroller, karotenoidler ve polifenolik bileşikler gibi çok sayıda doğal antioksidan içermesi sebebi ile serbest radikalleri temizleme, iyonları şelatlama ve hidrojen bağışlama gibi özelliklere sahip oldukları da iyi bilinmektedir. Sahip olduğu esansiyel yağların ve fenolik bileşiklerin antimikrobiyel aktiviteleri yine yapılan çalışmalarda da görülmektedir. Chia tohumunun sahip olduğu tüm bu özellikler kullanım alanının giderek arttığını ve chia ile ilgili çalışmalar üzerinde yoğunlaşılması gerektiğini göstermektedir.

\section{ÇIKAR ÇATIŞMASI BEYANI}

$\mathrm{Bu}$ çalışmada herhangi bir potansiyel çıkar çatışması bulunmamaktadır.

\section{YAZAR KATKILARI}

Yazarlar çalışmaya eşit oranda katkı sağlamıştır.

\section{KAYNAKÇA}

Akıc1, N. (2018). Bazı Salvia Türlerinin Biyokimyasal Özelliklerinin Belirlenmesi. Yüksek Lisans Tezi, Balıkesir Üniversitesi Fen Bilimleri Enstitüsü, Balıkesir.

Alcântara, M.A., Brito Polari, I.L., Albuquerque Meireles, B.R.L., Alcântara de Lima, A.E., Silva
Junior, J.C., Andrade Vieira, E., Albuquerque dos Santos, N., Magalhães Cordeiro, A.M.T. (2019). Effect of the solvent composition on the profile of phenolic compounds extracted from chia seeds. Food Chem., 275: 489-496.

Alonso-Calderón, A., Chávez-Bravo, E., Rivera, A., Montalvo-Paquini, C., Arroyo-Tapia, R., Monterrosas-Santamaria, M., Tapia-Hernández, A. (2013). Characterization of black chia seed (Salvia hispanica L.) and oil and quantification of $\beta$ sitosterol. Int J Biol Sci., 2(1): 70-72.

Arslan, N., Gürbüz, B., Gümüşçü, A. (2015). "Açıklamalı Tibbi ve Aromatik Bitkiler Rehberi." Ankara Üniversitesi, Ziraat Fakültesi Yayınları, 1620/572, 271-274, Ankara,

Ayerza, R., 2010. Effects of seed color and growing locations on fatty acid content and composition of two chia (Salvia hispanica L.) genotypes. J Am Oil Chem Soc., 87(10): 1161-1165.

Bayaz M. (2014) Paper Esansiyel Yağlar: Antimikrobiyel, Antioksidan ve Antimutajenik Aktiviteleri. Akademik. Gida, 12(3) 45-53.

Baykal, Y., Gök, F., Erikçi, S. (2002). Demir, serbest radikaller ve oksidatif hasar. Sendrom Aylık Tip Dergisi, 14 (1):94-100.

Beltrán -Orozco, M. C., Romero, M. R. (2003). La Chia, Alimento Milenario, Departamento de Graduados e Investigacion en Alimentos. ENCB, IPN, Mexico.

Bochicchio, R., Philips, TD., Lovelli, S., Labella, R., Galgano, F., Di Marisco, A., Perniola M., Amato M., (2015). Innovative crop productions for healthy food: the case of Chia (Salvia bispanica L.). The Sustainability of Agro-Food and Natural Resource Systems in the Mediterranean Basin. Springer Open, 29-45.Bodoira, R.M., Penci, M.C., Ribotta, P.D., Martínez, M. L. (2017). Chia (Salvia bispanica L.) oil stability: Study of the effect of natural antioxidants, LWT-Food Sci Tech., 75: 107113.

Brandão N. A., de Lima Dutra M. B., Ana Gaspardi L. A., Campos Maira R.S. (2019). Chia (Salvia bispanica L.) cookies: physicochemical/microbiological attributes, 
nutrimental value and sensory analysis. J Food Meas Charact., 13: 1100-1110.

Capitani, M. I., Spotorno, V., Nolasco, S. M., Tomás, M. C. (2012. Physicochemical and functional characterization of by-products from chia (Salvia hispanica L.) seeds of Argentina. LWTFood Sci Tech., 45(1): 94-102.

Campo C., dos Santos P. P. , Haas Costa T. M., Paese K., Guterres S. S., de Oliveira Rios A., Hickmann F. S. (2017). Nanoencapsulation of chia seed oil with chia mucilage (Salvia hispanica L.) as wall material: Characterization and stability evaluation. Food Chem., 234:1-9.

de Falco, B.; Amato, M.; Lanzotti, V. (2017). Chia seeds products: An overview. Phytochem Rev., 16: 745-760.

da Silva Marineli, R., Moraes, É. A., Lenquiste, S. A., Godoy, A. T., Eberlin, M. N., Maróstica Jr, M. R. (2014). Chemical characterization and antioxidant potential of Chilean chia seeds and oil (Salvia hispanica L.). LWT- Food Sci Tech., 59(2): 1304-1310.

Ding, Y., Lin, H.-W., Lin, Y.-L., Yang, D.-J., Yu, Y.-S., Chen, J.-W., Wang, S.-Y., Chen, Y.-C. (2018). Nutritional composition in the chia seed and its processing properties on restructured ham-like products. J Food Drug Anal., 26 (1): 124134.

Divyapriya G.K., Veeresh D.J., Yavagal P. C. (2016). Evaluation of Antibacterial Efficacy of Chia (Salvia Hispanica) Seeds Extract Against Porphyromonas Gingivalis, Fusobacterium Nucleatum and Aggregatibacter Actnomycetemcomitans-An InVitro Study. Int J Ayu Phar Res., 4(4):22-26.

Doğan H. (2019). Salvia hispanica L. Tohumlarının Fitokimyasal ve Biyolojik Aktivite Açısından Araştırılmas1, Yüksek Lisans Tezi, Anadolu Üniversitesi Sağlık Bilimleri Enstitüsü, Eskişehir.

Elshafie H. S., Aliberti L., Amato M., De Feo V., Camele I. (2018). Chemical composition and antimicrobial activity of chia (Salvia hispanica L.) essential oil. Eur Food Res Technol., 244:1675-1682

Anonim, (2021). https://www.cbi.eu/marketinformation/grains-pulses-oilseeds/chia- seeds/market-potential 24.01.2021).

Erdoğdu M. ve Geçgel Ü., (2019). Chia Tohumu (Salvia hispanica L.) ve Yağının Fizikokimyasal Özellikleri ve G1da Sektöründe Değerlendirilmesi, Gıda ve Yem Bilimi- Teknolojisi Dergisi, 21: 9-17.

Ertürk Ö., Aydın G., Çol Ayvaz M. (2020). Laurus nobilis L., Silybum marianum L., Nigella sativa L. ve Prunus cerasus L.'den Soğuk Pres Yöntemi ile İzole Edilen Esansiyel Yağ Bileşenlerinin Antimikrobiyel ve Antioksidan Aktiviteleri. Türk Tarım ve Doğa Bilimleri Dergisi, 7(2): 487-499.

Grancieri M., Martino H. S. D., de Mejia E. G. (2019). Chia Seed (Salvia hispanica L.) as a Source of Proteins and Bioactive Peptides with Health Benefits: A Review. Compr Rev Food Sci F., 18.

Goh K. K. T., Matia-Merino L., Chiang J. H., Quek R., Soh S. J. B., Lentle R. G. (2016). The physico-chemical properties of chia seed polysaccharide and its microgel dispersion rheology. Carbobyd Polym., 149:297-307.

Güzel S., Ülger M., Özay Y. (2020). Antimicrobial and Antiproliferative Activities of Chia (Salvia bispanica L.) Seeds. Int J Sec Met., 7 (3): 174-180.

Heck R.T., Vendruscolo R.G, de Araújo Etchepare M., Cichoski A.J., de Menezes C.R., Barin J.S., Campagnol P.C.B. (2017). Is it possible to produce a low-fat burger with a healthy $n-$ $6 / n-3$ PUFA ratio without affecting the technological and sensory properties. Meat Sci., 130:16-25.

Hrncic M. K., Ivanovski M., Cör D., Knez Ž. (2020). Chia Seeds (Salvia Hispanica L.): An Overview: Phytochemical Profile, Isolation Methods, and Application. Molecules, 25: 11.

Jin, F., Nieman, D. C., Sha, W., Xie, G., Qiu, Y., Jia, W. (2012). Supplementation of milled chia seeds increases plasma ALA and EPA in postmenopausal women. Plant Food Hum Nutr., 67(2): 105-110.

Kobus-Cisowska J., Szymanowska D., Maciejewska P., Kmiecik D., GramzaMichałowska A., Kulczyński B., Cielecka-Piontek J. (2019). In vitro screening for acetylcholinesterase and butyrylcholinesterase 
inhibition and antimicrobial activity of chia seeds (Salvia hispanica). Electron J Biotechn., 37: 1-10.

Kulczyński, B., Kobus-Cisowska, J., Taczanowski, M., Kmiecik, D., GramzaMichałowska, A. (2019). The Chemical Composition and Nutritional Value of Chia Seeds-Current State of Knowledge. Nutrients, 11: 1242.

Lee, A. (2009). The Effects of Salvia hispanica L. (Salba) on Postprandial Glycemia and Subjective Appetite. University of Toron, Nutritional Sciences, the degree of Master's of Science. Canada.

Lu, Y., Foo, L.Y. (2002). Polyphenolics of Salvia - a review. Phytochemistry, 59: 117-140.

Luo M., Caoa Y., Wangb W., Chenc X., Caia J., Wanga L., Xiao J. (2019). Sustained-release antimicrobial gelatin film: Effect of chia mucilage on physicochemical and antimicrobial properties. Food Hydrocoll., 87: 783-791.

Marcinek, K., Krejpcio, Z. (2017). Chia seeds (Salvia bispanica L.): health promoting properties and therapeutic applications-a review. Roczniki Państwowego Zakładu Higieny, 68(2):123-129.

Meyer, B., Groot, R. (2017). Effects of omega-3 long chain polyunsaturated fatty acid supplementation on cardiovascular mortality: The importance of the dose of DHA. Nutrients, 9(12):1305.

Orona-Tamayo, D., Valverde, M. E., ParedesLopez O. (2017). Chia-The New Golden Seed for the 21st Century: Nutraceutical Properties and Technological Uses. In book: Sustainable Protein Sources: 265-281.

Orozco, R.G., Duran, P.N., Gonzalez, E.D.R., Zaracúa, V.P., Ramirez, O.P. (2014). Proyecciones de cambio climático y potencial productivo para L. en las zonas agrícolas de México. Rev Mex Sci Agric., 10: 1831-1842.

Özgüven, M., S., Sekin, B., Gürbüz, N., Şekeroğlu, F., Ayanoğlu, S., Erken,. (2005). "Tütün, Tibbi ve Aromatik Bitkiler Üretimi ve Ticareti”, VI. Türkiye Ziraat Mühendisleri Teknike Kongresi Bildiri Kitabı, 1: 481-501.
Peiretti, P. G. and Gai, F. (2009). Fatty acid and nutritive quality of chia (Salvia hispanica L.) seeds and plant during growth. Anim Feed Sci and Tech., 148(2-4): 267-275.

Pellegrini, N., Serafini, M., Colombi, B., Del Rio, D., Salvatore, S., Bianchi, M. (2003). Total antioxidant capacity of plant foods, beverages and oils consumed in Italy assessed by three different in vitro assays. J Nutr., 33:2812-2819.

Rahman Md. J., Camargo A. C., Shahid F. (2017). Phenolic and polyphenolic profiles of chia seeds and their in vitro biological activities. J Func Food., 35: 622-634.

Reyes-Caudillo E., Tecante A., Valdivia-Lo'pez M. A. (2008). Dietary fibre content and antioxidant activity of phenolic compounds present in Mexican chia (Salvia hispanica L.) seeds, Food Chem., 107: 656-663.

Scapin, G., Schmidt, M. M., Prestes, R. C., Rosa, C. S. (2016). Phenolics compounds, flavonoids and antioxidant activity of chia seed extracts (Salvia hispanica) obtained by different extraction conditions Int Food Res J., 23(6): 2341-2346.

Segura-Campos, M. R., Ciau-Solís, N., RosadoRubio, G., Chel-Guerrero, L., Betancur-Ancona, D. (2014). Physicochemical characterization of chia (Salvia hispanica) seed oil from Yucatán, México. Agr Sci., 5(3): 220.

Sosa, A., Ruiz, G., Rana, J., Gordillo, G., West, H., Sharma, M., Liu X., de la Torre R. R. R. (2016). Chia Crop (Salvia hispanica L.): its History and Importance as a Source of Polyunsaturated Fatty Acids Omega-3 Around the World: a Review. J Crop Res Fert., 1: 1- 9.

Tamargo A., Cueva C., Laguna L., MorenoArribas M.V., Muñoz L. A. (2018). Understanding the impact of chia seed mucilage on human gut microbiotaby using the dynamic gastrointestinal model simgi. J Func Foods., 50: 10.

Timilsena, Y. P., Vongsvivut, J., Adhikari, R., Adhikari, B. (2017). Physicochemical and thermal characteristics of Australian chia seed oil. Food Chem., 228: 394-402.

Ullah, R., Nadeem, M. and Imran, M. (2017). Omega-3 fatty acids and oxidative stability of ice 
cream supplemented with olein fraction of chia (Salvia hispanica L.) oil. Lipids Health Dis.,16(1): 34.

USDA, 2020. United States Department of Agriculture Research Servise Food Composition Database. https://fdc.nal.usda.gov/fdcapp.html\#/food-details/1144211/nutrients (Erişim tarihi: 24 Ocak 2021). VillanuevaBermejo, D., Calvo, M.V., Castro-Gómez, P., Fornari, T., Fontecha, J. (2019). Production of omega 3-rich oils from underutilized chia seeds. Comparison between supercritical fluid and pressurized liquid extraction methods. Food Res. Int., 115, 400-407.

Vuksan, V., Choleva, L., Jovanovski, E., Jenkins, A. L., Au-Yeung, F., Dias, A. G., Duvnjak, L. (2017a). Comparison of flax (Linum usitatissimum) and Salba-chia (Salvia hispanica L.) seeds on postprandial glycemia and satiety in healthy individuals: a randomized, controlled, crossover study. Eur J Clin Nutr., 71(2): 234.
Vuksan, V., Jenkins, A. L., Brissette, C., Choleva, L., Jovanovski, E., Gibbs, A. L., Duvnjak, L. (2017b). Salba-chia (Salvia bispanica L.) in the treatment of overweight and obese patients with type 2 diabetes: A double-blind randomized controlled trial. Nutr Metab Cardiovasc Dis., 27(2): 138-146.

Wang X., Wang W., Peng M., Zheng X. Z. (2021). Free radicals for cancer theranostics. Biomaterials, 266: 120474.

Yurt, M., ve Gezer, C. (2018). Chia Tohumunun (Salvra hispanica) Fonksiyonel Özellikleri ve Sağllk Üzerine Etkileri. Doğu Akdeniz Üniversitesi, Sağllk Bilimleri Fakültesi, Beslenme ve Diyetetik Bölümü, Gazimağusa, KKTC. GIDA 43 (3): 446460.

Zettel V., Hitzmann B. (2018) Applications of chia (Salvia hispanica L.) in food products. Trends Food Sci Tech., 80: 43-50. 